Annamária Bene

Univerzitet u Novom Sadu

Učiteljski fakultet

na mađarskom nastavnom jeziku
УДК 004: 811.511.141'37

доИ https://doi.org/10.18485/

melissa.2016.15.2.ch6

\title{
NEKE OSOBINE DIGILEKTA MAĐARSKOG JEZIKA
}

\begin{abstract}
Sažetak
Digilekt je jezički varijetet koji nastaje posredstvom savremene informatičke tehnologije i/ili mobilne komunikacije i predstavlja novi vid pismenosti. Po svojim karakteristikama je međutim, vrlo sličan primarnoj usmenosti, to jest govoru, zbog se često naziva i pisanim govorom.

Ovaj rad bavi se osobinama mađarskog digilekta, koji se značajno razlikuje od standardnog mađarskog jezika. Najuočljivije je radikalno odstupanje od jezičke norme, koju prati radikalno jezičko osiromašenje s tim da se uporedo sa jezičkom divergencijom nastaje i nova jezička norma. Ovim digilektom upravlja jezička ekonomija, što kao krajnji rezultat ima vrlo raznovrsne oblike mađarskog digilekta.
\end{abstract}

Ključne reči: mađarski, digilekt, primarna i sekundarna pismenost i usmenost

\section{Uvod}

Generalno, ljudska komunikacija, to jest proces razmene informacija može biti verbalna i neverbalna. Neverbalna komunikacija odvija se pomoću neverbalnih znakova i podrazumeva gestikulaciju i govor tela, mimiku i govor očiju, dok verbalna komunikacija ima dva osnovna oblika: govor i pisanje. Verbalnu i neverbalnu komunikaciju karakterišu markantno različite osobine - ove različitosti svaki govornik koristi onako kako određena govorna situacija traži. U poslednje vreme zahvaljujući sve većoj rasprostranjenosti modernih tehničkih sredstava za komunikaciju, svedoci smo preplitanja pisane i govorne komunikacije, to jest pojave novog oblika pisane komunikacije koja odbacuje pravila standardne jezičke norme i pravopisa, ali u isto vreme stvara novu, alternativnu jezičku nor- 
mu i alternativna pravila pravopisa. To znači da se kao „posledica” digitalizacije govor i pisanje više ne mogu smatrati jedinim oblicima verbalne komunikacije, šta više, u digitalnoj eri menjaju se i sami oblici ljudske komunikacije (Balázs 2005).

U digitalnoj eri zahvaljujući preplitanju pisane i govorne komunikacije ne možemo više tvrditi da je proces razmene informacija isključivo verbalan ili isključivo neverbalan. Ali, polazeći od toga da se verbalni oblik komunikacije (još uvek) smatra primarnim, a neverbalni sekundarnim, možemo tvrditi to da ona sada ima oblike primarne usmenosti i pismenosti, i sekundarne usmenosti i pismenosti.

Primarna usmenost jeste govor: neposredna razmena informacija između najmanje dva govornika, a primarna pismenost znači tradicionalnu pismenost: posrednu razmenu informacija o vidu ostavljanja tragova pomoću prostih alata, npr. pera, olovke, krede na nekoj površini (pergamenu, papiru, tabli, zidu i sličnom).

Za nas je mnogo interesantnija sekundarna usmenost i pismenost, jer je ona nastala zahvaljujući tehnološkom razvoju, te ima odlike digitalizacije. Sekundarna usmenost jeste komunikacija posredstvom telekomunikacijske mreže pri čemu se koristi odgovarajuća oprema (npr. telefon, televizija, radio), a sekundarna pismenost je novi oblik pismenosti, koja nastaje posredstvom savremene informatičke tehnologije i/ili mobilne komunikacije. Tu spadaju mašinski pisani tekstovi (nastali pomoću programa za obradu tekstova, ali i tekstovi kucani na pisaćim mašinama), e-poruke, postovi, blogovi, tvitovi, četovi (putem interneta ili mobilne komunikacije), IM i sms (1. tabela). Interesantno je to da je ovaj novi vid pismenosti po svojim karakteristikama vrlo sličan primarnoj usmenosti, to jest govoru, zbog se često naziva i pisanim govorom.

\begin{tabular}{|c|c|c|c|}
\hline \multicolumn{2}{|c|}{ Ljudska komunikacija } \\
\hline $\begin{array}{c}\text { primarna } \\
\text { (neposredna razmena } \\
\text { informacija) }\end{array}$ & \multicolumn{2}{c|}{$\begin{array}{c}\text { sekundarna } \\
\text { (posredna razmena informacija) }\end{array}$} \\
\hline usmenost & pismenost & usmenost & pismenost \\
\hline govor & pisanje & $\begin{array}{c}\text { komunikacija putem } \\
\text { telekomunikacijske } \\
\text { mreže }\end{array}$ & $\begin{array}{c}\text { komunikacija pomoću savremenih } \\
\text { informacionih tehnologija i/ili } \\
\text { mobilne komunikacije }\end{array}$ \\
\hline
\end{tabular}

1. tabela 
Sekundarna pismenost je odraz digitalne upotrebe jezika, a njen proizvod jeste virtualni tekst: stručna literatura ima različite nazive za nju, ali s obzirom da ovaj rad razmatra osobine sekundarne pismenosti mađarskog jezika, koristiću naziv koji je najraprostranjeniji u mađarskoj lingvistici, a to je digilekt (Veszelszki 2010).

\section{Mađarski digilekt - koje su njene karakteristike?}

Mesto digilekta ili pisanog govora u sistemu jezičkih varijeteta teško je odrediti. Mađarska lingvistika definiše ga kao sociolekt, mediolekt, pa čak i kao stilističko sredstvo. Digilekt može biti definisan kao sociolekt zato što je jezički varijetet određene društvene grupe (Bódi 2004). Mediolektom ga smatramo jer se razmena informacija obavlja posredstvom medija (Löffler 2010), dok Szathmáry (2004) posmatra digilekt kao stilističko sredstvo, jer je rezultat društveno-kulturnih promena i predstavlja funkcionalno novi način iskazivanja - prenosa informacija.

Bez obzira na njegovo mesto u sistemu jezičkih varijeteta, mađarski digilekt se signifikantno razlikuje od standardnog mađarskog jezika, kako govornog, tako pisanog. Najuočljivija je jezička divergencija: radikalno odstupanje od jezičke norme, koju prati radikalno jezičko osiromašenje. Interesantno je, međutim, a ovo potvrđuju i naučna istraživanja, da jezičko ponašanje mlađe populacije govornika mađarskog jezika dovodi do formiranja nove jezičke norme: digilekt mađarskog jezika se u izvesnoj meri standardizuje (to je neminovno, jer pomaže razumevanje digilekta). To znači da digilekt ne predstavlja samo jezički varijetet, već u novu jezičku normu. Činjenica je istovremeno i to da populacija koja se koristi digilektom tačno zna kada treba da izvrši prebacivanje koda prilagođavajući se tako datim jezičkim situacijama.

Kod digilekta kriterijum brzine, a ona je osobina digitalnog prostora prevladava nad kriterijumom kvaliteta. To je razlog zbog čega su mađarski virtualni tekstovi izuzetno slični govoru: zbog kriterijuma brzine ovakvim tekstovima upravlja u mađarskom standardnom pravopisu nepostojeće fonetsko pravopisno načelo, to jest virtuelni tekstovi su u ovom slučaju doslovno pisani govori. Digilekt mađarskog jezika karakteriše i često 
izostavljanje dijakritičkih i interpunkcijskih znakova, što može otežati razumevanje teksta, i samim tim dovesti do zastoja u komunikaciji, ali i vrlo frekventno korišćenje emotikona.

Naravno, pisani govor se razlikuje i od pisanog, i od govornog teksta, a razlike su uočljive pre svega u segmentu metakomunikacije. Naime, kod ove vrste komunikacije nedostaje

- zajednički (fizički ili akustični) prostor,

- gestikulacija i mimika, i

- dikcija (akcenat, melodija, pauza, intonacija itd.).

Nedostatak poslednja dva segmenta metakomunikacije nadomešćuju se emotikonima, pošto oni stvaraju osećaj prisnosti u digitalnom prostoru (Wallace 2002).

Za digilekt mađarskog jezika tipična je jezička ekonomija, a ona se ispoljava kroz relativizaciju, negiranje pravila pravopisa, pa i samog pisanja kao oblika primarne razmene informacija, to jest kroz štednju na karakterima s ciljem što brže komunikacije. Sam uticaj jezičke ekonomije kao rezultat ima vrlo raznovrsne oblike mađarskog digilekta. $\mathrm{O}$ vi oblici se mogu svrstati u tri grupe.

U prvu grupu spadaju oblici koji imaju određene formalne osobine:

(1) Razni načini skraćivanja reči:

a. skraćivanje prvog sloga reči koje počinju samoglasnikom: hnap (holnap 'sutra'), vki (valaki 'neko'),

b. umesto reči pojavljuje se samo početni samoglasnik: $\boldsymbol{m}$ (mert 'zbog'), sb (semmi baj 'nema problema'),

c. skraćenice izvedene uzimanjem početnih samoglasnika slogova: kv (kávé 'kafa'),

d. skraćenice višesložnih reči izvedene uzimanjem prvog i poslednjeg sloga: talunk (találkozunk 'srešćemo se'),

e. Skraćivanje idioma: $\boldsymbol{R I A}$ (Eridj $a . .$. ! $\rightarrow$ Idi u...! , s tim da reč je eridj je dialektološki oblik (standardni je eredj), ali je postao i deo digilekta).

(2) Pravopisne greške:

a. fonetsko pisanje reči: mennyünk (menjünk 'idemo'), hüje (hülye 'budala'), eccer (egyszer 'jednom'), télleg (tényleg 'stvarno'), 
b. nepoštovanje pravila pisanja malih i velikih početnih slova: peti (Peti 'Perica, Pera'),

c. pisanje isključivo malim slovima: én nem akartam (Én nem akartam. 'Ja nisam hteo/htela.'),

d. izostavljanje interpunkcijskih i dijakritičkih znakova: nezd el kerlek (Nézd el, kérlek. 'Molim te, zažmuri na jedno oko.').

(3) Multipliciranje slova i/ili interpunkcijskih znakova: Neeeeeem akaroooooooooooom!!!!!!!!!!! (Nem akarom! 'Ne želim!'), Mi??????? (Mi? 'Molim?').

(4) Kombinovanje raznih znakova:

a. kombinovanje slova i brojeva:

5let (ötlet 'ideja' $\rightarrow$ slog öt- i mađarski naziv broja 5: öt predstavljaju slučaj homofonije i homografije, ali ne i homonimije),

7vége (hétvége $\rightarrow$ reč hét u složenici hétvége znači 'nedelja', ali je i homonim, jer znači i broj 7),

Lm1 (elmegy 'odlazi' $\rightarrow$ izgovor prepozicije el poklapa se sa izgovorom slova $L$ 'el', egy može biti izgovor broja 1 , ali u ovom primeru egy nije slog, nego samo deo sloga, tačnije jednosložnog glagola megy 'ići'),

7fö (hétfö 'ponedeljak' $\rightarrow$ reč hét i ovde znači 'nedelja', ali je i homonim, jer znači i broj 7),

60adik (hatvanadik'šezdeseti ' $\rightarrow$ hatvan $=60$ )

jó8 (jó éjt 'laku noć' $\rightarrow$ reč éjt 'noć-Acc' poklapa se sa izgovorom broja 8 u engleskom: /:eit/).

b. Kombinacije slova, brojeva i drugih znakova:

+6ott (meghatott 'ganut' $\rightarrow$ prepozicija meg je homograf i homofon reči meg, koja može značiti 'još', 'i' ili 'dodati', i to je prikazano znakom +, dok je glagol hat 'uticati', 'delovati' homograf i homofon reči hat 'šest', i zato je prikazan brojem 6),

\}olat (kapcsolat 'veza, odnos' $\rightarrow$ vitičasta zagrada liči na kopču, a prvi slog izvedene reči kapcsolat je u stvari imenički koren od reči kapocs 'kapocs'),

,dni (vesződni 'mučiti se' $\rightarrow$ u mađarskom reč vessző znači 'zarez', i zato se u ovoj skraćenici vidi interpukcijski znak', s tim 
da u samoj reči deo vesző- nema nikakve veze sa rečju vesszó), 1xü (egyszerü 'jednostavan/a/o' $\rightarrow$ slog egy je homograf i homofon reči egy 'jedan', slog szer- može imati značenje 'puta', i zato je zamenjen znakom množenja).

(5) Među formalne karakteristike digilekta brojimo i korišćenje emotikona.

Sledeću grupu čine oblici sa leksičkim osobinama. Tu spadaju strane, najčešće engleske reči i izrazi, i to u raznim oblicima:

(1) Engleske reči pisane po pravilima engleskog pravopisa - ovaj način pisanja stranih reči u stvari propisuje mađarski pravopis: no comment, party.

(2) Engleske reči pisane fonetski: lájk, fész = face Facebook, láv, láw, cset.

(3) Engleske reči sa mađarskim tvorbenim morfemama:

light-os $\rightarrow U$ ovom slučaju su ispoštovana pravila mađarskog pravopisa koja uređuju pisanje i sufiksaciju stranih reči.

gózzunk 'idemo!' $\rightarrow$ Ovaj oblik imperativa nastao je tako što je engleski glagol to go 'ići' prvo dobio denominalni(!) tvorbeni sufiks $-z(i k)$, verovatno radi lakšeg izgovora, (ali i zbog toga što u mađarski jeziku ne mogu postojati koreni koji se završavaju kratkim samoglasnikom), zatim je dodat nastavak imperativa -j, koji se promenio u -z-, i na kraju lični nastavak za 1. lice množine.

lájkol 'lajkuje', csetel 'četuje' $\rightarrow$ Kod ova dva slučaja pored fonetskog pisanja vidimo i upotrebu denominalne tvorbene morfeme $-I$, najproduktivnije tvorbene morfeme savremenog mađarskog jezika.

(4) Engleski akronimi, npr.: btw = by the way 'uzgred', $\boldsymbol{g t g}=$ got to go 'moram da idem', brb = be right back 'odmah se vraćam', asap = 'što pre', OMG = 'O, moj bože', Iol = 'glasno se smejem'.

(5) Među leksičke osobine mađarskog digilekta spadaju i neologizmi: a. nove reči (pr. kuffervizit = 'proveriti ko je prisutan u četrumu', finger=lista prijavljenih u četrum), ili

b. izrazi (ki van a faxom $\rightarrow$ 'pun mi je...!'; U mađarskom izrazu pejorativno ime muškog polnog organa zamenjeno je imenicom 
fax 'faks = uređaj za slanje kopija dokumenata', jer se ove dve reči razlikuju u jednom slovu.).

Mađarski digilekt pokazuje i gramatičke karakteristike, kao što su:

(1) greške vezane za pogrešnu upotrebu padežnih sufikasa -ba/-be i -ban/-ben: délbe umesto délben i obrnuto.

(2) Vrlo su česta razna odstupanja od pravila građenja rečenica. Najčešće se pojavljuju nepotpune rečenice: Pénteken a halastónál sörözés? 'U petak kod ribnjaka pivo?' i neraščlanjene rečenice: én nem akartam de ez lett 'ja nisam htela/o ali ovo se desilo'.

\section{Zaključak}

Digitalna era ne znači samo savremenu informatičku tehnologiju i komunikaciju, već i do sada neviđeno ubrzanje razmene informacija, i nastanak novih oblika i načina jezičkog izražavanja. Njihova pojava je nevinovnost, jer su odraz digitalne upotrebe jezika i predstavljaju novi vid pismenosti koju stručna literatura naziva digilektom. Ova pismenost je po svojim karakteristikama vrlo slična primarnoj usmenosti, to jest govoru.

Tema ovog rada je mađarski digilekt. S obzirom da je ovaj jezički varijetet izuzetno raznovrstan, predstavljene su samo neke njene formalne, leksičke i gramatičke osobine. Posmatrajući mađarski digilekt može se reći da je najupadljiviji masivan uticaj engleskog jezika i izražena jezička divergencija. Imajući u vidu da je mađarski puristički jezik, vrlo je verovatno da će se zbog ove dve tendencije u budućnosti ovaj digilekt postati samostalni, urbani dijalekt ovog jezika.

\section{Literatura}

Balázs, Géza. Az internetkorszak kommunikációja. In Balázs, Géza - Bódi, Zoltán eds. Az internetkorszak kommunikációja. Tanulmányok. Budapest: Gondolat-Infonia, 2005. 25-57.

Bódi, Zoltán. A világháló nyelve. Internetezők és internetes nyelvhasználat a magyar társadalomban. Budapest: Gondolat Kiadó, 2004. 
Löffler, Heinrich. Germanistische Soziolinguistik. 4., neu bearbeitete Auflage (=Grundlagen der Germanistik, Band 28.). Berlin: Erich Schmidt Verlag, 2010.

Szathmáry, István. Stilisztikai lexikon: stilisztikai fogalmak magyarázata szépirodalmi példákkal szemléltetve. Budapest: Tinta Könyvkiadó, 2004.

Veszelszki, Ágnes. Digilektus a lektusok rendszerében. In Illés-Molnár, Márta - Kaló, Zsuzsa - Klein, Laura - Parapatics, Andrea eds. Félúton 5. Az ELTE BTK Nyelvtudományi Doktori Iskolájának konferenciája. Budapest: ELTE Nyelvtudományi Doktori Iskola, 2010. 199-215.

Wallace, Patricia. Az internet pszichológiája. Budapest: Osiris Kiadó, 2002.

\title{
Annamária Bene \\ University of Novi Sad
}

\section{SOME FEATURES OF HUNGARIAN DIGILECT}

\begin{abstract}
Summary
A digilect is a newly developed variety of a language which development is triggered by computer-mediated communication, and can be regarded as a sociolect, a mediolect or even as a stylistic device. It combines spoken and written communication, ie. the main forms of verbal communication with secondary literacy represented by some modern communication tools, thus generating the written speech, a brand new form of literacy, which resembles in many ways to the spoken language, even though it lacks some properties typical of metacommunication.

The digilect of Hungarian is ruled by a principle called Ockham's razor, which is regarded in linguistics as the principal economy principle. Because of this the digilect of Hungarian is a language variety heavily marked by word abbreviations, deviations from and changes in orthography, and frequent use of emoticons. In point of lexical properties, the Hungarian digilect is characterized by great influence of foreign languages, mainly English, as well as significant number of neologisms and discourse markers. Amongst grammatical features Hungarian digilect exhibits e.g. linguistic reductions: mainly simplification of words, frequent use of grammatical particles, ellipses, and conscious or unconscious speech errors; it should be also noted that in this language variety coordinate clauses are much more frequent then subordinate clauses.
\end{abstract}

Key words: digilect, Hungarian, written speech, Ockham's razor 